\title{
Relationships between Cadmium in Tissues of Cacao Trees and Soils in Plantations of Trinidad and Tobago
}

\author{
Gideon Ramtahal ${ }^{*}$, Ivan Chang Yen1, Isaac Bekele², Frances Bekele3 ${ }^{3}$, Lawrence Wilson², \\ Kamaldeo Maharaj ${ }^{4}$, Lisa Harrynanan ${ }^{4}$ \\ ${ }^{1}$ Department of Chemistry, University of the West Indies, St. Augustine, Trinidad and Tobago \\ ${ }^{2}$ Department of Food Production, University of the West Indies, St. Augustine, Trinidad and Tobago \\ ${ }^{3}$ Cocoa Research Centre, University of the West Indies, St. Augustine, Trinidad and Tobago \\ ${ }^{4}$ Ministry of Food Production, Centeno, Trinidad and Tobago \\ Email: "gtahal@hotmail.com
}

Received 23 November 2015; accepted 23 January 2016; published 26 January 2016

Copyright (C) 2016 by authors and Scientific Research Publishing Inc.

This work is licensed under the Creative Commons Attribution International License (CC BY).

http://creativecommons.org/licenses/by/4.0/

cc) (i)

Open Access

\begin{abstract}
The primary source of cadmium in cocoa beans has been linked to its direct uptake by the cacao plant from cadmium contaminated soils. This research was conducted to evaluate and interpret significant relationships between cadmium levels in tissues of the cacao plant and soils from cocoa-growing areas in Trinidad and Tobago. Total $\left(\mathrm{HNO}_{3}\right.$-extractable) concentrations of cadmium in both tissues and soils were determined. The levels of cadmium measured varied in the order: leaves $>$ pods $>$ shells $>$ nibs $>$ soil. Cadmium levels in all the cacao tissues analyzed were significantly $(\mathrm{p}<0.05)$, positively and strongly correlated with each other. Additionally, significant $(\mathrm{p}<$ 0.05) positive relationships were also identified between $\mathrm{Cd}$ in cacao tissues and corresponding total $\mathrm{HNO}_{3}$-extractable $\mathrm{Cd}$ levels in soils. These findings suggest that they can possibly be used as predictive tools for assessing Cd levels in cacao.
\end{abstract}

\section{Keywords}

Cadmium, Cacao, Soils, Relationships

\section{Introduction}

Contamination of soils with heavy metals is an increasing problem globally and a threat to environmental biota,

\footnotetext{
*Corresponding author.
} 
as these metals accumulate in soils and plants [1] [2]. In plants, some metals, including copper, zinc and nickel, are considered essential micronutrients [3]; however, when present in excess, these essential and non-essential heavy metals, such as cadmium (Cd), can accumulate to toxic levels in the tissues of plants used for human or animal nutrition [4].

Generally, the intake of Cd in very small amounts by humans is unavoidable, with agricultural produce being a major source [5]. However, its toxicity can present significant health risks if Cd-contaminated foodstuffs are consumed [6] [7]. Health effects include abdominal cramps, headaches, vomiting and diarrhea [8]. With longterm exposure, Cd causes renal damage [9], severe loss of bone minerals and painful fractures [10].

Over the years, foods such as vegetables [11] [12] rice [10] and other cereals [13] [14] and shellfish [15] have been monitored for Cd contamination. Also of great public significance are the levels of Cd in cocoa beans, cocoa powders and cocoa liquors used for chocolate production [1] [16]-[19]. The Cd content in chocolates is a function of the cocoa bean nib content and diminishes in the order: bitter chocolate (used for baking), dark chocolate (bittersweet and semi-sweet), milk chocolate and white chocolate [18]. It is thus not surprising that food safety concerns have been generated over the presence and levels of $\mathrm{Cd}$ in cocoa, as many consume these products daily. As a result, international legislative bodies, as well as chocolate manufacturing countries, have introduced new regulations for the protection of the health of their consumers [20]-[22] in addition to pending stricter EU standards [23].

It is claimed that Cd levels in cocoa beans are due to their uptake by cacao plants from soils [17]. Some soils, especially those of volcanic origins, can contain high levels of Cd, which can be taken up by the cacao plant and concentrated in the beans [24]. Cadmium is not reported to be essential for any biological process in plants [25], but is still absorbed by both root and leaf systems from soils [26]-[29]. Since Cd in cacao is absorbed from soils and subsequently distributed among its various tissues [16] [17], including leaves, pods and beans, the reduction of Cd uptake from soils is a major strategy for its reduction in beans, to allow producers to meet increasingly stringent food safety standards for cocoa products. However, it is first necessary to determine any correlations in Cd levels among the various cacao tissues and soils of cacao estates to better understand the mechanisms of uptake and distribution in cacao tissues as well as to determine the effectiveness of soil treatments to reduce Cd uptake.

In this study, Cd levels among cacao leaves, pods, bean nibs, testae/shells and soils, on which cacao trees were grown, were determined and compared, to identify whether it was possible to relate soil Cd with cacao tissues and especially cacao beans (nibs) from which edible products were derived. Such correlations can be used to assess the effectiveness of soil treatments to reduce $\mathrm{Cd}$ uptake and redistribution in cacao tissues, especially the nibs. The potential to estimate cadmium levels in cacao beans via correlations with other cacao tissues was also investigated, to provide a basis for subsequent studies in Cd absorption and distribution in cacao trees. A recent study of cadmium in cacao tissues and soils in Ecuador [30] focused largely on cadmium correlations between beans and soils and possible origins of contamination, but not between cacao tissues, as done in this study.

\section{Materials and Methods}

All water used for sample preparation and cleaning of glassware in this study was glass-distilled and deionized. To avoid trace metal contamination, all laboratory glassware and utensils used were washed with a commercial detergent and tap water, immersed in a $2 \mathrm{M}$ nitric acid $\mathrm{HNO}_{3}$ (J.T. Baker, USA) bath for at least $24 \mathrm{~h}$, then rinsed with distilled deionized water before drying in an oven at $50^{\circ} \mathrm{C}$. All reagents used for sample preparation and analyses in this study were of analytical grade and were tested in blank analyses, to correct for Cd background levels.

\subsection{Collection and Preparation of Samples}

Cacao samples were collected from 45 plantations throughout different cacao-growing locations on all major soil types (I-VII) in Trinidad and Tobago (Table 1). At each sampling site, 8 - 12 cacao trees were randomly selected and soil cores ( 0 - $30 \mathrm{~cm}$ depth) taken with an auger around the drip zone of each tree, since cacao trees have extensive feeding root systems close to the surface [31]. From each tree sampled, cacao tissues, namely mature and sound leaves and ripe pods, were randomly taken and placed in polyethylene bags, tied at the mouths, immediately labeled for identification and transported to the laboratory for processing. 
Table 1. Distribution of soil physical and chemical properties across the different locations sampled.

\begin{tabular}{|c|c|c|c|c|c|c|c|}
\hline \multirow{2}{*}{ Characteristic } & \multicolumn{7}{|c|}{ Soil type } \\
\hline & I & II & III & IV & $\mathrm{V}$ & VI & VII \\
\hline Sand (\%) & 31 & 64 & 47 & 35 & 33 & 25 & 19 \\
\hline Silt (\%) & 18 & 7 & 21 & 20 & 17 & 14 & 10 \\
\hline Clay (\%) & 42 & 25 & 29 & 49 & 32 & 59 & 33 \\
\hline $\mathrm{pH}$ & 4.9 & 4.5 & 4.9 & 4.9 & 5.3 & 7.6 & 6.2 \\
\hline $\mathrm{EC}\left(\operatorname{mhos} \times 10^{6}\right)$ & 37 & 43 & 138 & 16 & 41 & 99 & 55 \\
\hline CEC (meq/100g) & 11.5 & 4.7 & 8.2 & 8.5 & 4.4 & 6.3 & 34.2 \\
\hline OM (\%) & 1.55 & 1.03 & 2.41 & 0.86 & 1.89 & 3.96 & 0.52 \\
\hline Base saturation (\%) & 18 & 13 & 49 & 28 & 32 & 100 & 100 \\
\hline Ca (meq/100g) & 1.3 & 0.5 & 3.5 & 1.8 & 0.8 & 8.0 & 15.6 \\
\hline $\mathrm{Mg}(\mathrm{meq} / 100 \mathrm{~g})$ & 7 & 0.2 & 0.7 & 0.9 & 0.7 & 0.4 & 31.1 \\
\hline
\end{tabular}

From each cacao pod, the beans were removed and rinsed in deionized water to remove excess mucilage. The beans were then oven-dried on glass plates at $105^{\circ} \mathrm{C}$ for $4-5 \mathrm{~h}$, separated into nibs and shells, and each ground separately in ceramic mortars to $<1 \mathrm{~mm}$ diameter particle size. Pod husks were rinsed with deionized water, grated finely $(<1 \mathrm{~mm})$ on a plastic grater and dried on glass plates at $105^{\circ} \mathrm{C}$ for $3 \mathrm{~h}$. Leaves were washed with deionized water, chopped to $<1 \mathrm{~mm}$ in a food processor, then oven-dried on aluminum foil at $105^{\circ} \mathrm{C}$ for about 24 h. Soil samples were air-dried for $48 \mathrm{~h}$, ground and sieved through a $2 \mathrm{~mm}$ sieve, as recommended for soil analyses [32]. Each dried sample was placed in a clean polyethylene bag, mixed well, labeled and stored until needed for analysis.

\subsection{Extraction and Analysis of Samples}

\subsubsection{Determination of Cd in Cacao Tissues}

The method of determination for Cd in cacao tissues was optimized for highest recovered levels, using local samples of cacao leaves, pods, nibs and shells or testae. Sample mass: acid volume, digestion conditions and extraction times were systematically varied, to determine the highest levels of Cd recovered from each sample type. For these analyses, optimal recoveries were obtained for $0.5 \mathrm{~g}$ aliquots of nib, shells, pod and leaf samples, to each of which $10 \mathrm{~mL}$ concentrated $\mathrm{HNO}_{3}$ (J.T. Baker, USA) were added and samples allowed to pre-digest at room temperature for $12 \mathrm{~h}$, followed by complete digestion on a heating block at $130^{\circ} \mathrm{C}$ for 6 h. Digested extracts were cooled, diluted with $5 \mathrm{~mL}$ distilled water, filtered through Whatman No. 542 filters and made up to $25 \mathrm{~mL}$, for Cd determination by flame atomic absorption spectrometry (FAAS).

Reference Cocoa Materials certified for Cd were unfortunately unavailable to our laboratory at the time of the study, necessitating the use of NIST SRM 1570a Spinach Leaves, (National Institutes of Standard and Technology, Maryland, USA), to validate the test method. Replicate analyses $(n=10)$ of this SRM were done. Once validated, this method was used to analyze all cacao tissues samples, with appropriate instrumental and sample quality control measures taken, to maintain the accuracy of analyses. Quality control results shown in Table 2.

\subsubsection{Determination of Total $\mathrm{HNO}_{3}$-Extractable $\mathrm{Cd}$ in Soil}

As for cacao tissues, the method of determination of total Cd in soil was similarly optimized, using a soil sample from a local cocoa farm. For optimal extractions, to triplicate $0.5 \mathrm{~g}$ aliquots of soil samples, $10 \mathrm{~mL}$ concentrated $\mathrm{HNO}_{3}$ was added to each and samples pre-digested at room temperature for $12 \mathrm{~h}$, followed by exhaustive digestion on a heating block at $130^{\circ} \mathrm{C}$ for $8 \mathrm{~h}$. Digested extracts were cooled, diluted with $5 \mathrm{~mL}$ distilled water, filtered through Whatman No. 542 filters and made up to $25 \mathrm{~mL}$, for Cd determinations by FAAS.

A Certified Reference Soil, namely NIST SRM 2710 Montana Soil was analyzed in replicate $(\mathrm{n}=10)$ with this method and \% recoveries for Cd determined. Appropriate quality control measures, as done with cacao 
Table 2. Mean cadmium concentrations \pm Std. deviation and \% recoveries from NIST Certified Reference Materials SRM1570a and SRM 2710.

\begin{tabular}{ccccc}
\hline & Certified value $(\mu \mathrm{g} / \mathrm{g})$ & Mean, $\mathrm{n}=23$ triplicates $(\mu \mathrm{g} / \mathrm{g})$ & \% Recovery & CV \\
\hline SRM 1570a (Spinach leaves) & $2.89 \pm 0.07$ & $2.69 \pm 0.05$ & 95.5 & 4.71 \\
SRM 2710 (Montana soil) & $21.80 \pm 0.2$ & $21.58 \pm 0.31$ & 99.00 & 1.43 \\
\hline
\end{tabular}

tissues were also taken to maintain accuracy of analyses. Results of quality control for soil samples are shown in Table 2.

\section{Statistical Analysis}

Correlation analyses used to evaluate and interpret significant relationships between the selected heavy metal concentrations in various cacao sample types were done with Minitab 16 software.

\section{Results and Discussion}

Data generated from 23 sets of replicate analyses of leaf and soil CRM over the 18-month experimental period, including 10 replicates for method validation, are shown in Table 2. The mean CRM recoveries for cadmium for each sample type over this period were consistent with their certified values (Table 2). In addition, the RSD values $(<10 \%)$ for each metal determined demonstrate the high precision and reproducibility of the test method.

\subsection{Cadmium Concentrations in Cacao Tissues and Soils Sampled}

More than $50 \%$ of the locations sampled contained detectable $(>0.3 \mu \mathrm{g} / \mathrm{g}) \mathrm{Cd}$ in the cacao tissues sampled. Generally, Cd levels measured in the tissues of the cacao plants varied in the order: leaves $(0.54-5.21 \mu \mathrm{g} / \mathrm{g})>$ pods $(0.53-4.49 \mu \mathrm{g} / \mathrm{g})>$ shells $(0.44-4.41 \mu \mathrm{g} / \mathrm{g})>$ nibs $(0.35-3.82 \mu \mathrm{g} / \mathrm{g})$. This trend is consistent with some previous reports of differing Cd levels among organs or tissues in the same plant [16] [17] [33], but differs from those reported for Ecuadorean cacao [30], possibly because of differences in germplasm [34]. Its distribution in the cacao tree may be as a result of the mobilization of protective mechanisms in plants, which inhibit the transport of metals to other tissues and organs [35].

Conversely, the total $\mathrm{HNO}_{3}$-extractable concentrations of $\mathrm{Cd}$ in soils sampled across cacao plantations ranged from $0.3-1.7 \mu \mathrm{g} / \mathrm{g}$. These levels were generally lower than those of cacao tissues of trees grown on the soils, consistent with previous reports [16]. Recycling of underlying organic materials such as leaf and pod materials on soils of plantations can contribute to uptake of Cd by cacao plants [16] [17]. It may also be due to the volcanic nature of soils in a few areas sampled, bearing in mind that volcanic soils can contain high levels of Cd [24]. In addition, it was noted that some of these areas were either prone to flooding during the wet season, with the possibility of Cd contamination from industrial sources [10] [36], or in some cases had a long history of fertilizer applications. Phosphate fertilizers are known to be contaminated with Cd [37] and have contributed to elevated levels of Cd in soil in cacao plantations in Malaysia [38].

\subsection{Correlation Analysis of Cd in Cacao Tissues and Soils}

Correlation analyses were used to evaluate and interpret significant relationships for Cd concentrations in the various cacao tissues (Table 3).

Cadmium levels in all the cacao tissues analyzed were significantly $(\mathrm{p}<0.05)$, positively and strongly correlated with each other: (Nib/Shell) $r=0.86$; (Nib/Leaf) $r=0.79$; (Nib/Pod) $r=0.76$; (Shell/Leaf) $r=0.83$; (Shell/Pod) $r=0.68$ ); and (Leaf/Pod) $r=0.80$. This indicates that the concentrations of Cd concentrations in cacao nibs, shells, leaves and pods vary proportionately with each other. It also suggests that the Cd distribution and concentration ratios within tissues are related. Such strong correlations suggest that cadmium levels in cacao beans can be estimated through its other tissues, when pods are not available. This may offer a means of early screening of cacao cultivars for cadmium accumulation, for selecting low-cadmium varieties, to allow cacao growers to meet the proposed European Union standard [23] for cadmium in beans. 
Table 3. Pearson correlation coefficients (r) between Cd levels in cacao tissues and soil.

\begin{tabular}{ccccc}
\hline & Cd (Nib) & Cd (Shell) & Cd (Leaf) & Cd (Pod) \\
\hline Cd (Shell) & $\mathbf{0 . 8 6}$ & & & \\
Cd (Leaf) & $\mathbf{0 . 7 9}$ & $\mathbf{0 . 8 3}$ & $\mathbf{0 . 8 0}$ & \\
Cd (Pod) & 0.76 & $\mathbf{0 . 6 8}$ & $\mathbf{0 . 3 4}$ \\
Cd (Soil) & 0.35 & 0.43 & 0.50 \\
\hline
\end{tabular}

Bold values are significant at $\mathrm{p}<0.05$.

Significant $(\mathrm{p}<0.05)$ relationships were also identified between Cd in cacao tissues and corresponding total $\mathrm{HNO}_{3}$-extractable Cd levels in soils: (Nib/Soil) $\mathrm{r}=0.35$; (Shell/Soil) $\mathrm{r}=0.43$; (Leaf/Soil) $\mathrm{r}=0.34$; and $(\mathrm{Pod} / \mathrm{Soil})$ $r=0.50$. It is notable that such correlations were obtained for a wide variety of cacao cultivars and soil types and should be applicable to other cacao-growing countries.

It is well known that most plants which accumulate heavy metals in their aerial tissues primarily reflect the concentrations of their respective metal in the soil [39]. However, although significant ( $<0.05$ ), the correlations obtained with local soils were also weak, suggesting that the measurement of total Cd may not be appropriate for estimating metal availability to plants. The bioavailability of metals in soils for uptake by plants is often not the same as their total metal concentrations, since only a fraction may be available for absorption [40]. The study on Ecuadorean cacao tissues and soils [30] demonstrated that selective extraction methods for soil cadmium provide stronger correlations between cacao beans and soils. Subsequent to the present study, it was shown that bioavailable soil Cd determined using single-extractant protocols such as DTPA, AB-DTPA and EDTA are strongly correlated with tissues of cacao plants grown on Cd-contaminated soils [41]. Future studies on the uptake and distribution of Cd from soils to cacao tissues should therefore use bio-available instead of total extractable Cd.

\section{Conclusion}

This study demonstrated that strong and significant correlations exist between Cd levels in cacao tissues over a wide range of cacao cultivars. These findings suggest that it may be possible to predict Cd levels in cocoa beans from those in mature leaves and pods. This can be especially useful in assessing cacao trees, growing areas and soil types for possible elevated Cd levels in beans, even when pods are unavailable. Such an approach can be used by cacao farmers and purchasing agents of cocoa beans to estimate whether beans from any farm or area are likely to meet specific Food Safety Standards for Cd. Similarly, the effectiveness of soil treatments to minimize Cd uptake from soils by cacao plants can be monitored through tissue Cd levels before and following remedial soil treatments.

\section{Acknowledgements}

The authors are grateful for the generous financial and logistical support provided by the Government of Trinidad and Tobago, through the Ministry of Food Production and staff members Davinan Ramnath and Ian Rampersad. The assistance of the Cocoa and Coffee Industry Board of T \& T, the Cocoa and Coffee Marketing Co-Operative Society Ltd. and local cocoa farmers in the provision of samples and the administrative support of the University of the West Indies, St. Augustine are also highly appreciated.

\section{References}

[1] Jalbani, N., Kazi, T.G., Afridi, H.I. and Arain, M.B. (2009) Determination of Toxic Metals in Different Brands of Chocolates and Candies, Marketed in Pakistan. Pakistan Journal of Analytical and Environmental Chemistry, 10, 4852.

[2] Ololade, I.A. and Ologundudu, A. (2007) Concentration and Bioavailability of Cadmium by Some Plants. African Journal of Biotechnology, 6, 1916-1921.

[3] Misra, S. and Mani, D. (2009) Soil Pollution. S. B Nangia APH Publishing Corporation, New Delhi, 29-59.

[4] Valerie, P. and Feller, U. (2005) Selective Transport of Zinc, Manganese, Nickel, Cobalt and Cadmium in the Root 
System and Transfer to the Leaves in Young Wheat Plants. Annals of Botany, 96, 425-434. http://dx.doi.org/10.1093/aob/mci189

[5] Chaudri, A.M., Allaina, C.M.G., Badawya, S.H., Adamsa, M.L., McGratha, S.P. and Chambersc, B.J. (2001) Cadmium Content of Wheat Grain from a Long-Term Field Experiment with Sewage Sludge. Journal of Environmental Quality, 30, 1575-1580. http://dx.doi.org/10.2134/jeq2001.3051575x

[6] Jarup, L., Berglund, M., Elinder, C., Nordberg, G. and Vahter, M. (1998) Health Effects of Cadmium. Exposure a Review of Literature and a Risk Estimate. Scandinavian Journal of Work, Environment and Health, 24, 1-52.

[7] Auroville Center for Urban Research (ACUR) (2003) Heavy Metals and Pesticides Residue in the Foodstuff, Annexes-Final Report. Auroville Innovative Urban Management IND-015.

[8] Agency for Toxic Substances and Disease Registry (ATSDR) (1993) Toxicological Profile for Cadmium. U.S. Department of Health and Human Services, Public Health Service, Atlanta.

[9] Harrison, N. (2001) Inorganic Contaminants in Food: Metals and Metalloids. In: Watson, D, Ed., Food Chemical Safety: Contaminants, Vol. 1, Chapter 7, CRC Press, Florida.

[10] Reilly, C. (2002) Transition Metals. In: Metal Contamination of Food: Its Significance for Food Quality and Human Health, 3rd Edition, Blackwell Publishing, UK, 160-165.

[11] Nabulo, G. (2004) Assessment of Heavy Metal Contamination in Food Crops and Vegetables from Motor Vehicle Emissions in Kampala City. A Technical Report Submitted to IDRC-AGROPOLIS Uganda Department of Botany, Makerere University, Kampala.

[12] Beccaloni, E., Vanni, F., Beccaloni, M. and Carere, M. (2013) Concentrations of Arsenic, Cadmium, Lead and Zinc in Homegrown Vegetables and Fruits: Estimated Intake by Population in an Industrialized Area of Sardinia, Italy. Microchemical Journal, 107, 190-195. http://dx.doi.org/10.1016/j.microc.2012.06.012

[13] Adams, M.L., Zhao, F.J., McGrath, S.P., Nicholson, F.A., Chalmers, A., Chambers, B.J. and Sinclair, A.H. (2001) Evaluation of Factors Affecting the Cadmium and Lead Content of British Wheat and Barley. HGCA Report No. 265, HGCA London.

[14] Balyan, H.S., Gupta, P.K., Kumar, S., Dhariwal, R., Jaiswal, V., Tyagi, S., Agarwal, P., Gahlaut, V. and Kumari, S. (2013) Genetic Improvement of Grain Protein Content and Other Health-Related Constituents of Wheat Grain. Plant Breeding, 132, 446-457. http://dx.doi.org/10.1111/pbr.12047

[15] Storelli, M.M. (2008) Potential Human Health Risks from Metals (Hg, Cd and Pb) and Polychlorinated Biphenyls (PCBs) via Seafood Consumption: Estimation of Target Hazard Quotients (THQs) and Toxic Equivalents (TEQs). Food and Chemical Toxicology, 46, 2782-2788. http://dx.doi.org/10.1016/j.fct.2008.05.011

[16] Lee, C.K. and Low, K.S. (1985) Determination of Cadmium, Lead, Copper and Arsenic in Cocoa, Semi-Finished and Finished Chocolate Products. Pertanika, 8, 243-248.

[17] Fauziah, C.I., Zaharah, A.R., Zauyah, S. and Anuar, A.R. (2001) Proposed Soil Heavy Metal Reference Values to Be Used for Site Assessment. Proceedings of Brownfield 2001: First National Conference on Contaminated Land, Petaling Jaya, The Institution of Engineers, Malaysia.

[18] Mounicou, S., Szpunar, J., Andrey, D., Blake, C. and Lobinski, R. (2003) Concentrations and Bioavailability of Cadmium and Lead in Cocoa Powder and Related Products. Food Additives and Contaminants, 20, 343-352. http://dx.doi.org/10.1080/0265203031000077888

[19] Dahiya, S., Karpe, R., Hegde, A.G. and Sharma, R.M. (2005) Lead, Cadmium and Nickel in Chocolates and Candies from Suburban Areas of Mumbai, India. Journal of Food Composition and Analysis, 8, 517-522. http://dx.doi.org/10.1016/j.jfca.2004.05.002

[20] Ducos, S., Hamester, M. and Godula, M. (2010) ICP-MS for Detecting Heavy Metals in Foodstuffs: The Technology Can Analyze 50 Samples in an Hour. http://www.foodquality.com/details/article/809781/ICPMS_for_Detecting_Heavy_Metals_in_Foodstuffs_html?tzchec $\underline{\mathrm{k}=1}$

[21] Dickson, H. (2010) The Analysis of Cadmium in Chocolate by Graphite Furnace Atomic Absorption Spectrometry. Thermo Fisher. Scientific. http://www.Analiticaweb.com.br/newsletter/10/43034_CadmiumChocolate_AA.pdf

[22] European Food Safety Authority (EFSA) (2011) Metals as Contaminants in Food. http://www.efsa.europa.eu/en/topics/topic/metals.htm

[23] Gray, N. (2014) EU Adopts New Measures to Limit Cadmium in Food. http://www.foodnavigator.com/Policy/EU-adopts-new-measures-to-limit-cadmium-in-food

[24] Beckett, S.T. (2009) Industrial Chocolate Manufacture and Use. 3rd Edition, Chap. 2, Wiley-Blackwell, Ames.

[25] United States Environmental Protection Agency (USEPA) (2011) Technical Fact Sheet for Cadmium. http://www.epa.gov/ogwdw000/pdfs/factsheets/ioc/tech/cadmium.pdf 
[26] Adriano, D.C. (2001) Trace Elements in Terrestrial Environments: Biogeochemistry, Bioavailability and Risk of Metals. 2nd Edition, Springer-Verlag, New York, Chap. 6, 522. http://dx.doi.org/10.1007/978-0-387-21510-5

[27] Kabata-Pendias, A. (2001) Trace Elements in Soils and Plants, 3rd Edition, CRC Press, Chap. 6, 295.

[28] Benavides, M.P., Gallego, S.M. and Tomaro, M.L. (2005) Cadmium Toxicity in Plants. Brazilian Journal of Plant, Physiology, 17, 49-55. http://dx.doi.org/10.1590/S1677-04202005000100003

[29] Gratão, P.L., Polle, A., Lea, P.J. and Azevedo, R.A. (2005) Making the Life of Heavy Metal-Stressed Plants a Little Easier. Functional Plant Biology, 32, 481-494. http://dx.doi.org/10.1071/FP05016

[30] Chavez, E., He, Z.L., Stoffella, P.J., Mylavarapu, R.S., Li, Y.C., Moyano, B. and Baligar, V.C. (2015) Concentration of Cadmium in Cacao Beans and Its Relationship with Soil Cadmium in Southern Ecuador. Science of the Total Environment, 533, 205-214. http://dx.doi.org/10.1016/j.scitotenv.2015.06.106

[31] Butler, D.R., Maharaj, K. and Sukha, D.A. (2004) The Agro-Ecology of Cocoa in Trinidad and Tobago. In: Wilson, L.A., Ed., Revitalisation of the Trinidad \& Tobago Cocoa Industry: Proceedings of the APASTT Seminar/Exhibition, 20 September 2003, St. Augustine, Trinidad, Association of Professional Agricultural Scientists of Trinidad and Tobago, 39-48.

[32] Tan, K.H. (2005) Soil Sampling, Preparation, and Analysis. 2nd Edition, Taylor \& Francis/CRC Press, Boca Raton.

[33] Wu, F., Dong, J., Qian, Q.Q. and Zhang, G.P. (2005) Subcellular Distribution and Chemical Form of Cd and Cd-Zn Interaction in Different Barley Genotypes. Chemosphere, 60, 1437-1446. http://dx.doi.org/10.1016/j.chemosphere.2005.01.071

[34] Cryer, N. and Hadley, P. (2012) Cadmium Uptake and Partitioning within the Cocoa Plant. International Workshop on Cadmium in Cocoa and Chocolate Products, London, 3-4 May 2012. http://www.icco.org/sites/sps/documents/Cadmium\%20Workshop/Reading\%20University.pdf

[35] Sêkara, A., Poniedzialek, M., Ciura, J. and Jedrszczyk, E. (2005) Cadmium and Lead Accumulation and Distribution in the Organs of Nine Crops: Implications for Phytoremediation. Polish Journal of Environmental Studies, 14, 509-516.

[36] International Programme on Chemical Safety (IPCS) (2010) Environmental Health Criteria 135 (EHC 135): Cadmium-Environmental Aspects. http://www.inchem.org/documents/ehc/ehc/ehc135.htm

[37] Lambert, R., Grant, C. and Sauvé, S. (2007) Cadmium and Zinc in Soil Solution Extracts Following the Application of Phosphate Fertilizers. Science of the Total Environment, 378, 293-305. http://dx.doi.org/10.1016/j.scitotenv.2007.02.008

[38] Zarcinas, B.A., Ishak, C.F., McLaughlin, M.J. and Cozens, G. (2004) Heavy Metals in Soils and Crops in Southeast Asia Peninsular Malaysia. Environmental Geochemistry and Health, 26, 343-357. http://dx.doi.org/10.1007/s10653-005-4669-0

[39] Saxena, P. and Misra, N. (2010) Remediation of Heavy Metal Contaminated Tropical Land. In: Sherameti, I. and Varma, A., Eds., Soil Heavy Metals, Soil Biology, Vol. 19, Springer-Verlag, Berlin, 431-477. http://dx.doi.org/10.1007/978-3-642-02436-8 19

[40] Prokop, Z., Cupr, P., Zlevorova-Zlamalikova, V., Komarek, J., Dusek, L. and Holoubek, I. (2003) Mobility, Bioavailability and Toxic Effects of Cadmium in Soil Samples. Environmental Research, 91, 119-126. http://dx.doi.org/10.1016/S0013-9351(02)00012-9

[41] Ramtahal, G. (2012) Investigations of Heavy Metals in Cocoa in Trinidad and Tobago. PhD Dissertation, The University of the West Indies, St. Augustine. 